\title{
Rural Women's Participation in Cattle Management Activities
}

\author{
Afsana* and Dhriti Solanki \\ Department of EECM, CCAS, MPUAT, Udaipur, India \\ *Corresponding author
}

\section{A B S T R A C T}

\section{Keywords \\ Cattle Management Activities, livestock \\ Article Info \\ Accepted: \\ 12 August 2020 \\ Available Online: \\ 10 September 2020}

\begin{abstract}
Women play a major role in livestock in India. They assume many activities relating to livestock production like feeding of animals, cure of animals, watering of animals, and collection of fuel, milking, feeding, and cleaning of animal sheds. The present study focuses on the participation of rural women in different activities related to cattle management. A sample of 100 rural was selected purposely from Girwa block of Udaipur, Rajasthan. Data were collected using personal interview technique. The results show that milk processing, care of cow, cleaning of animal shed, watering of animals, making feed concentrates and feeding of cattle were the main activities performed by rural women. Their participation in most of the cattle management practices was medium to high.
\end{abstract}

\section{Introduction}

In India, rural women besides their involvement in agriculture have been traditionally and predominately engaged in animal husbandry and dairy activities. There are 75 million women engaged in dairying as against 15 million men and 20 million in animal husbandry as compared to 1.5 million men. Women today are central to the selection, breeding, cultivation, preparation \& harvest of food crops (Ghosh and Ghosh, 2014). The crucial role of women in agriculture and allied activities has been grossly under estimated and undervalued. However, many of the important tasks in animal husbandry are performed by women besides their responsibilities as home maker and caring of animals is considered as an extension of domestic activities. It is estimated that 600 million poor livestock keepers in the world, around two-third are women and most live in rural areas (Thornton et al., 2002). Rural women are also responsible for collection, preparing dung cakes an activity that also brings additional income to poor families. Evidently, rural women are involved in almost all livestock related activities.

The credit of growth in the livestock sector goes to women. The present investigation has been undertaken with the objective to study the participation of rural women in cattle management activities. 


\section{Materials and Methods}

The study was conducted in Girwa block of Udaipur district, Rajasthan state. Families owning seven to eight cattle heads were selected for study. A sample of 100 rural women was selected purposely. One female member shouldering the responsibilities in cattle management from each family represented the study sample. The data were collected personally with the help of structured interview schedule. Data collected were statistically analyzed with the help of frequency and percentage.

\section{Results and Discussion}

\section{Background information of the respondents}

Table 1 depicts that 46 per cent of the respondents were in the age group of 20-28 years, 41 per cent were in the age group of 29-37 and 13 per cent belonged to middle age group category i.e. 38-45 years. Educational profile of the respondents shows that majority of them were having primary education $(28.0 \%)$ followed by middle school $(16.0 \%)$, higher secondary $(10 \%)$, illiterate $(19 \%)$ and college educated $(8 \%)$. It was also observed that majority of the respondents belonged to nuclear family whereas 48 per cent respondents belonged to joint family. Results on marital status showed that majority of respondents were married followed by unmarried (23\%), widow (8\%). Regarding family education, majority $(60.6 \%)$ of the respondents were laborers followed by farming $(46.0 \%)$. Majority of the respondents (56\%) belonged to low income category followed by medium (22\%) and low (22\%). Regarding herd size, 66 per cent families had small herd size consisting of 1-4 animals and 34 per cent had medium herd size of 4-8 animals.

\section{Participation of rural women in cattle management activities}

In the present investigation, an attempt was made to know the extent of participation of farm women in cattle management activities. The findings pertaining to this are presented as under:

\section{Component wise participation}

Component- wise participation of the respondents was assessed in order to have thorough knowledge regarding the women's participation in various cattle management practices. The findings related to this are presented in Table 2.

With regard to participation of women in breeding activities cursory of Table 2 depicts that decision regarding selection of breed was taken jointly with male members by 41 per cent of the respondents while 40 per cent respondents were not involved in the activity. The task of detection of heat in the cattle was done either independently (33\%) or jointly with male members by 49 per cent respondents. Similarly activities like diagnosis of pregnancy, care of pregnant cow and care of new born calf were performed independently by 33,48 and 51 per cent respondents, respectively and jointly by $42-47$ per cent respondents. Majority of the respondents $(59 \%)$ were not involved in artificial insemination activity. The women reported that they have not adopted the practice of artificial insemination in cattle. The activity of sterilization of male calf was performed jointly by 50 per cent respondents where as 50 per cent respondents were not at all involved in it. Calf birth related activities like cleaning, feeding colostrum, cutting of naval cord, dehorning, etc were performed jointly by majority (61\%) of the respondents. Maintenance of record of pregnant cow and postnatal care were the activities performed 
either independently or jointly by the respondents.

Findings related to participation of women in feeding practices reveals that activities like preparation of animal feed $(56 \%)$, cutting of fodder $(53 \%)$ and soaking feed $(67 \%)$ were performed independently by the women. Joint participation of women was observed in activities like cultivation of fodder (55\%), cutting and assembling of fodder (66\%), watering cattle $(56 \%)$ and storage of fodder $(66 \%)$. Majority of the respondents were not involved in preparation of mineral mixture for cattle $(57 \%)$ as only 43 per cent respondents were feeding mineral mixture to cattle. The responsibility of feeding cattle was performed independently and jointly by equal number of respondents $(50 \%)$.

Table.1 Background information of the respondents $n=100$

\begin{tabular}{|c|c|c|}
\hline S.No. & Characteristics & $\mathbf{f} / \%$ \\
\hline 1 & $\begin{array}{l}\text { Age } \\
\text { Young (18-30 years) } \\
\text { Lower middle ( } 31-45 \text { years) } \\
\text { Upper middle ( } 46-60 \text { years) }\end{array}$ & $\begin{array}{l}46 \\
41 \\
13\end{array}$ \\
\hline 2 & $\begin{array}{l}\text { Education } \\
\text { Illiterate } \\
\text { Primary } \\
\text { Can read and write } \\
\text { Middle school } \\
\text { High school } \\
\text { Post metric diploma } \\
\text { Graduate and above }\end{array}$ & $\begin{array}{c}19 \\
26 \\
13 \\
16 \\
10 \\
8 \\
8\end{array}$ \\
\hline 3 & $\begin{array}{l}\text { Family type } \\
\text { Joint } \\
\text { Nuclear }\end{array}$ & $\begin{array}{l}48 \\
52\end{array}$ \\
\hline 4 & $\begin{array}{l}\text { Marital status } \\
\text { Married } \\
\text { Unmarried } \\
\text { Widow }\end{array}$ & $\begin{array}{c}69 \\
23 \\
8\end{array}$ \\
\hline 5 & $\begin{array}{l}\text { Occupation } \\
\text { Farming } \\
\text { Labor } \\
\text { Artisan }\end{array}$ & $\begin{array}{l}46 \\
54\end{array}$ \\
\hline 6 & $\begin{array}{l}\text { Income } \\
\text { Low } \\
\text { Medium } \\
\text { High }\end{array}$ & $\begin{array}{l}56 \\
22 \\
22\end{array}$ \\
\hline 7 & $\begin{array}{l}\text { Land } \\
\text { Landless } \\
\text { Marginal (1.0 to } 2.5 \text { acre) } \\
\text { Small ( } 2.6 \text { to } 5 \text { acre) } \\
\text { Large (above } 5 \text { acre) }\end{array}$ & $\begin{array}{c}20 \\
69 \\
- \\
11\end{array}$ \\
\hline 8 & $\begin{array}{l}\text { Herd Size } \\
\text { Small (1- } 4 \text { milch animals) } \\
\text { Medium (5-8 milch animals) } \\
\text { Large ( more than } 8 \text { animals) }\end{array}$ & $\begin{array}{c}66 \\
34 \\
-\end{array}$ \\
\hline
\end{tabular}


Table.2 Distribution of respondents by their participation in cattle management activities $n=100$

\begin{tabular}{|c|c|c|c|c|}
\hline S.No. & Statement & $\begin{array}{l}\text { Independently } \\
(\mathbf{f} / \%)\end{array}$ & $\begin{array}{l}\text { Jointly With Male } \\
\text { Members (f/\%) }\end{array}$ & $\begin{array}{c}\text { No } \\
\text { Participation } \\
(\mathbf{f} / \%)\end{array}$ \\
\hline 1. & BREEDING & & & \\
\hline 1. & Selection of breed & 19 & 41 & 40 \\
\hline 2. & Detection of heat & 33 & 49 & 18 \\
\hline 3. & Pregnancy diagnosis & 33 & 42 & 7 \\
\hline 4. & Care of pregnant cow & 48 & 45 & 7 \\
\hline 5. & Care of new born calf & 51 & 47 & 2 \\
\hline 6. & Artificial insemination & 2 & 39 & 59 \\
\hline 7. & $\begin{array}{l}\text { Sterilization of male } \\
\text { Calf }\end{array}$ & 9 & 41 & 50 \\
\hline 8. & $\begin{array}{l}\text { Calf birth related } \\
\text { Activities }\end{array}$ & 38 & 61 & 1 \\
\hline 9. & $\begin{array}{l}\text { Maintain record of } \\
\text { every pregnant cow }\end{array}$ & 30 & 40 & 30 \\
\hline 10. & Postnatal care & 45 & 50 & 5 \\
\hline 2. & FEEDING & & & \\
\hline 1. & Cultivation of fodder & 1 & 55 & 44 \\
\hline 2. & Cutting and assembling of fodder & 13 & 66 & 21 \\
\hline 3. & Preparation of animal feed & 56 & 44 & 0 \\
\hline 4. & Cutting of fodder & 53 & 47 & 0 \\
\hline 5. & Watering cattle & 44 & 56 & 0 \\
\hline 6. & Soaking feed & 67 & 33 & 0 \\
\hline 7. & $\begin{array}{l}\text { Carrying cattle to } \\
\text { Pastures }\end{array}$ & 20 & 49 & 31 \\
\hline 8. & Preparation of mineral mixture & 6 & 37 & 57 \\
\hline 9. & Storage of fodder & 0 & 68 & 32 \\
\hline 10. & Feeding cattle & 50 & 50 & 0 \\
\hline 3. & HEALTH CARE & & & \\
\hline 1. & Care of sick cattle & 36 & 48 & 16 \\
\hline 2. & Control of internal parasites & 18 & 52 & 30 \\
\hline 3. & Control of external parasites & 12 & 32 & 56 \\
\hline 4. & Taking sick cattle to the hospital & 5 & 42 & 53 \\
\hline 5. & Vaccination & 1 & 51 & 48 \\
\hline 6. & $\begin{array}{l}\text { Care and management of pregnant animal } \\
\text { at the time of parturition }\end{array}$ & 25 & 51 & 24 \\
\hline 7. & Giving first aid to sick animals & 32 & 64 & 4 \\
\hline 4. & MANAGEMENT & & & \\
\hline 1. & Cleaning of cattle shed & 68 & 32 & 0 \\
\hline 2. & Milking & 61 & 39 & 0 \\
\hline 3. & Storage of milk & 80 & 20 & 0 \\
\hline 4. & Cleaning of stockyard & 62 & 38 & 0 \\
\hline 5. & Bathing of animals & 60 & 40 & 0 \\
\hline 6. & Making cow dung cake & 100 & 0 & 0 \\
\hline 7. & Bringing water for animals & 59 & 41 & 0 \\
\hline 8. & Taking animals for drinking water outside & 43 & 57 & 0 \\
\hline
\end{tabular}


Table.3 Distribution of the respondents by their extent of participation in cattle management activities

\begin{tabular}{|c|c|c|}
\hline S.No. & Category & $\mathbf{f} / \%$ \\
\hline $\mathbf{1 .}$ & Low & 10 \\
\hline $\mathbf{2 .}$ & Medium & 20 \\
\hline $\mathbf{3 .}$ & High & 70 \\
\hline
\end{tabular}

Regarding health care of cattle, it was found that taking care of sick cattle was the joint responsibility of both man and woman in 48 per cent cases where as in 36 per cent cases it was performed independently by the women. In case of control of internal parasites, the activity was performed jointly by man and woman in 52 per cent cases whereas, in 30 per cent cases women were not involved in the activity. The respondents $(30 \%)$ reported that control of internal parasites is the sole responsibility of male. Similarly majority $(56 \%)$ of the respondents was not involved in activity control of external parasites and they reported that this task is mainly performed by male members. Taking sick cattle to the hospital was the responsibility of both man and women in 44 per cent cases whereas, 53 per cent of the women were not involved in this activity and they reported that it is taken care of by the male members of the family. Vaccination and care \& management of pregnant animal at the time of parturition was done jointly by 51 per cent respondents. Similarly the task of giving first aid to sick animals was performed jointly by majority (64\%) of the respondents.

The next major activity where women participated actively was management of cattle. The work of making dung cake, to store milk, cleaning of cattle shed, cleaning of stockyard and milking were also largely performed by women. The table indicate that women performed activities like bathing of animals (60\%), bringing water for animals (59\%) and taking animals for drinking water outside (43\%). Similar findings are reported by Rathod et al., (2012).

\section{Over all participation}

To know the overall participation of the respondents in cattle management activities, they were grouped into three categories viz. low, medium and high participation. The results are presented in Table 3.

Table 3 reveals that majority of the respondents $(70 \%)$ were in the category of high level of participation whereas, 20 per cent respondents belonged to medium level of participation and 10 per cent respondents were in the low participation category.

\section{References}

Ghosh, M. M. and Ghosh, A. 2014. Analysis of Women Participation in Indian Agriculture. Journal of Humanities\& Social Science. 19(5):01-06

Thornton, P.K., Kruska, R.L., Henninger, N., Kristjanson, P.M., Reid, R.S., Atieno, F., Odero, A.N. and Ndegwa, T. 2002. Mapping poverty and livestock in the developing world. Nairobi, International Livestock Research Institute (ILRI) (available at http://www.ilri.org/ InfoServ/Webpub/fulldocs/InvestAnim/B ook2/media/PDF_chapters/B2_Front.pdf)

\section{How to cite this article:}

Afsana and Dhriti Solanki. 2020. Rural Women's Participation in Cattle Management Activities. Int.J.Curr.Microbiol.App.Sci. 9(09): 1351-1355. doi: https://doi.org/10.20546/ijcmas.2020.909.171 